\title{
Spines, Plasticity, and Cognition in Alzheimer's Model Mice
}

\author{
Tara Spires-Jones ${ }^{1}$ and Shira Knafo² \\ ${ }^{1}$ Massachusetts General Hospital, Harvard Medical School, 114 16th Street, Charlestown, MA 02129, USA \\ ${ }^{2}$ Centro de Biología Molecular "Severo Ochoa," Consejo Superior de Investigaciones Científicas (CSIC) and \\ Universidad Autónoma de Madrid, Nicolás Cabrera, 28049 Madrid, Spain \\ Correspondence should be addressed to Tara Spires-Jones, tspires@partners.org and Shira Knafo, sknafo@cbm.uam.es
}

Received 12 September 2011; Accepted 27 October 2011

Academic Editor: Xiao-Xin Yan

Copyright ( $) 2012$ T. Spires-Jones and S. Knafo. This is an open access article distributed under the Creative Commons Attribution License, which permits unrestricted use, distribution, and reproduction in any medium, provided the original work is properly cited.

The pathological hallmarks of Alzheimer's disease (AD)—widespread synaptic and neuronal loss and the pathological accumulation of amyloid-beta peptide $(\mathrm{A} \beta)$ in senile plaques, as well as hyperphosphorylated tau in neurofibrillary tangleshave been known for many decades, but the links between AD pathology and dementia and effective therapeutic strategies remain elusive. Transgenic mice have been developed based on rare familial forms of AD and frontotemporal dementia, allowing investigators to test in detail the structural, functional, and behavioral consequences of AD-associated pathology. Here, we review work on transgenic $\mathrm{AD}$ models that investigate the degeneration of dendritic spine structure, synaptic function, and cognition. Together, these data support a model of $\mathrm{AD}$ pathogenesis in which soluble $\mathrm{A} \beta$ initiates synaptic dysfunction and loss, as well as pathological changes in tau, which contribute to both synaptic and neuronal loss. These changes in synapse structure and function as well as frank synapse and neuronal loss contribute to the neural system dysfunction which causes cognitive deficits. Understanding the underpinnings of dementia in $\mathrm{AD}$ will be essential to develop and evaluate therapeutic approaches for this widespread and devastating disease.

\section{Introduction}

Alzheimer's disease $(\mathrm{AD})$ is a devastating progressive neurodegenerative disease characterized by cognitive decline, brain atrophy due to neuronal and synapse loss, and the formation of two pathological lesions, extracellular amyloid plaques composed largely of amyloid-beta peptide $(\mathrm{A} \beta)$, and neurofibrillary tangles, intracellular aggregates of hyperphosphorylated tau protein $[1,2]$.

The brain is a remarkably adaptable network of neurons sharing information through approximately $10^{14}$ synaptic connections. The plasticity of this network in response to environmental stimuli enables the brain to adapt to new demands and allows learning and the formation of new memories. Changes of synapses and dendritic spines, the postsynaptic element of most excitatory synapses, in response to stimulation are thought to underlie the brain's plasticity [3]. It follows that disruption of neural circuits due to both synapse loss and decline in the ability of remaining spine synapses to change in response to stimuli likely contribute to the disruption of cognition observed in neurodegenerative diseases such as Alzheimer's disease. Indeed, it is known that synapses are lost during $\mathrm{AD}$ and that, in $\mathrm{AD}$ tissue, synapse loss correlates strongly with cognitive decline, arguing the importance of this process as causative to dementia [4-7].

Rare familial forms of $\mathrm{AD}$ occur in which amyloid precursor protein (APP), the precursor to the A $\beta$ peptide, or presenilin (PS) 1 or 2, the catalytic subunit of the gamma-secretase complex which cleaves APP to form $\mathrm{A} \beta$, are mutated and result in an autosomal dominant, earlyonset form of the disease [8]. Mutations in the tau protein have not been found to cause $\mathrm{AD}$ but can lead to familial frontotemporal dementia with Parkinsonism linked to chromosome $17[9,10]$. These mutations strongly implicate amyloid processing as an instigating factor in the disease and also provide genetic tools for the construction of transgenic mouse models of the disease which recapitulate many of its pathological features [11]. In contemporary $\mathrm{AD}$ research, these transgenic models are being used to characterize 
the physiological and behavioral consequences of $\mathrm{AD}$ neuropathology in order to investigate the fundamental question of the underlying anatomical causes of dementia. APP and APP/PS1 transgenic mice express high levels of amyloid beta $(\mathrm{A} \beta)$ and progressively develop many of the pathological phenotypes of $\mathrm{AD}$, including abundant extracellular $\mathrm{A} \beta$ plaques, synaptic dysfunction and loss, astrocytosis, activation of microglia, and cognitive deficits [12]. For decades, $\mathrm{A} \beta$ plaques were thought to cause dementia in $\mathrm{AD}$ patients by physically interrupting normal neural connectivity and function. However, the lack of correlation between $A \beta$ plaque load and the degree of cognitive impairment in $\mathrm{AD}$ patients [4] and the fact that $\mathrm{A} \beta$ plaques occupy a negligible fraction (less than 5\%) of the neuropil [13-15] in cognitively impaired transgenic mice [15] raised the possibility that fibrillar $\mathrm{A} \beta$ in plaques does not contribute significantly to dementia in $\mathrm{AD}$ patients. Instead, soluble $\mathrm{A} \beta$ species (i.e., monomeric, oligomeric, and protofibrillary $A \beta$ species that linger in aqueous solution after high-speed centrifugation) seem to be the main culprits of the functional deficits in these mice and probably also in initiating disease in $\mathrm{AD}$ patients.

Mice expressing dementia-associated tau mutations have also been developed to study the contributions of neurofibrillary pathology to dementia and the interplay between $\mathrm{A} \beta$ and tau $[16,17]$. While genetic studies clearly implicate amyloid as the initiating factor in $\mathrm{AD}$, the correlation of tangles with neuronal loss in $\mathrm{AD}$ brain, together with the lack of neuronal loss and tangle formation in APP transgenic models, and the lack of efficacy with $\mathrm{A} \beta$-directed therapeutics have contributed to the idea that tau pathology is an important contributor to dementia downstream of $\mathrm{A} \beta$ [18].

This paper will review the work on dendritic spine changes and their contribution to functional changes in synapses and behavioral deficits in AD models. It is important to address these questions because the ability of synapses and spines to change even in aged brain and the strong correlation between synapse loss and cognitive decline in $\mathrm{AD}$ indicate that enhancing spine plasticity could prevent or even reverse cognitive deficits associated with neurodegenerative disease.

\section{In Vivo Imaging Reveals Dendritic Spine Loss and Plaque-Associated Structural Plasticity Deficits in AD Models}

Dendritic spines form the postsynaptic element of the vast majority of excitatory synapses in the cortex and hippocampus brain regions important for learning and memory. Changes in spines are thought to be a structural basis for these processes [3]. Loss of dendritic spines similar to the synapse loss observed in human $\mathrm{AD}$ has been reported in several mouse models that develop amyloid and tau pathology [13, 19-25]. The use of mouse models for in vivo multiphoton imaging allows longitudinal investigations to determine the temporal sequence of pathological events and to answer "chicken-or-egg" questions such as which comes first, spine loss or plaques? In order to perform these experiments, it is first necessary to fluorescently label dendritic spines and pathological lesions such as plaques and tangles. Spines can be imaged with transgenic expression of fluorophores such as GFP and YFP [2629] or through filling neurons with fluorescent dextrans [30] or fluorescent proteins expressed in adeno-associated virus or lentivirus $[21,31]$. To label plaque pathology in AD models, the blood-brain barrier-penetrable compounds, Pittsburghs compound $\mathrm{B}$ and methoxy-XO4 (developed by William Klunk), have been used in conjunction with in vivo multiphoton imaging to observe amyloid plaques and their clearance after treatment with immunotherapy [32-35].

Imaging of amyloid plaques together with imaging dendrites and dendritic spines filled with fluorescent proteins can be used to assess the effects of pathology on the surrounding neuropil (Figure 1). This technique shows that plaques form rapidly, over the course of one day, and that within one week of plaque formation, surrounding dendrites begin to curve and exhibit dystrophic swellings [36]. Spine loss around plaques was determined to be due to a loss of stability of spines in the vicinity of plaques with more spine elimination than that in control brain, reflecting dysfunctional structural plasticity [37]. These structural plasticity changes contribute to functional deficits around plaques. In one study, neural circuit function was assessed using a fluorescent reporter of neuronal activation (the coding sequence of Venus, flanked by short stretches of the $5^{\prime}$ and $3^{\prime}$ untranslated regions from CamKII $\alpha$ ) which gets transported to dendrites and locally translated in response to activity resulting in increased fluorescence in dendrites after neuronal activation. APP/PS1 transgenic mice have greatly reduced levels of this reporter in dendritic segments surrounding plaques, and they failed to upregulate its expression in response to environmental stimulation, a phenomenon which was robust in wild-type animals [38]. Resting intraneuronal calcium levels are also disrupted around plaques, indicating dysfunction [39].

From the above studies, it is clear that plaques affect local dendrites and dendritic spines, but the precise bioactive molecule around plaques which induces spine loss was not clear for many years. The strongest candidate for the synaptotoxic molecule around plaques arose as soluble oligomeric A $\beta$ due to work by William Klein, Dennis Selkoe, and other groups who reported that soluble $\mathrm{A} \beta$ causes dendritic spine collapse and impairs synaptic plasticity in culture [40-44], correlates with memory loss in transgenic mice $[45,46]$, and impairs memory and synaptic plasticity in vivo [47, 48]. In further support of the synaptotoxic role of $A \beta$, both active and passive immunotherapy to remove $A \beta$ have favorable effects on memory, plaque clearance, and neurite architecture in $\mathrm{AD}$ models [33,49-53]. The first direct assessment of whether oligomeric $A \beta$ is present at synapses in the brain came from application of the array tomography technique to $\mathrm{AD}$ mouse brain tissue. Array tomography, developed by Micheva et al., overcomes the axial resolution limitation of confocal microscopy by physically sectioning tissue into $70 \mathrm{~nm}$ ribbons of serial sections which can then be used for immunofluorescent analysis to accurately quantify the contents of small structures such as synapses [54, 55]. 


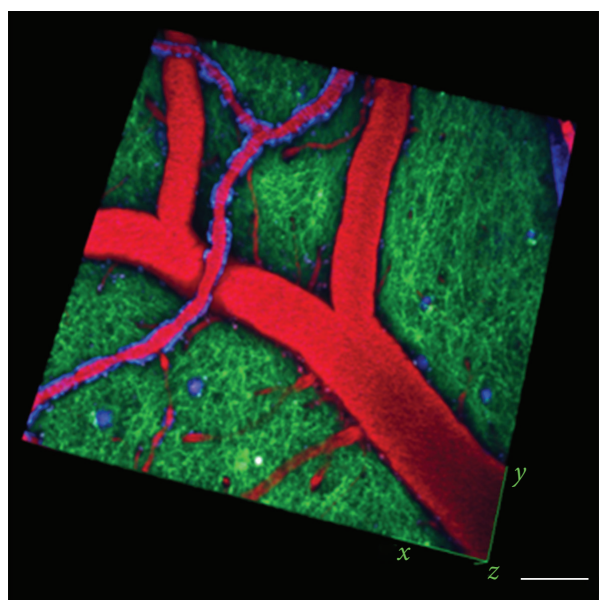

(a)

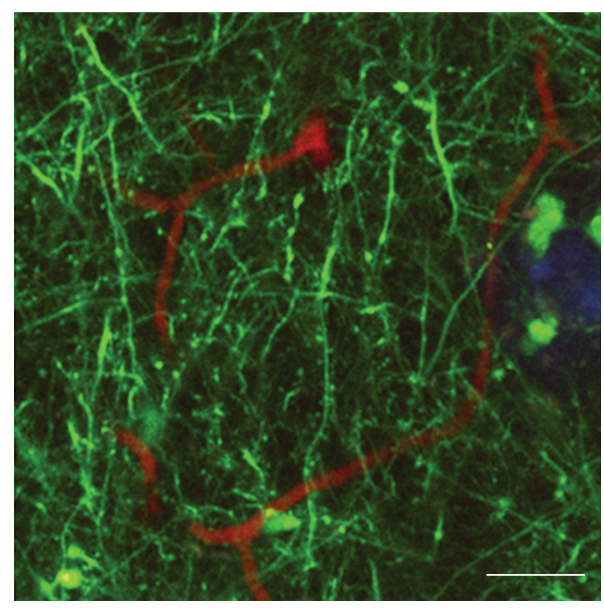

(b)

Figure 1: In vivo multiphoton imaging of plaques (labeled with methoxy X-O4, blue), vasculature (labeled with Texas red dextran, red), and dendrites (transgenically expressing YFP, green) in mice transgenic for mutant human APP and PS1 crossed with YFP transgenic mice allow examination of dendritic spine plasticity and loss. Low-resolution three-dimensional image stacks (a) are used to repeatedly find the same imaging sites. Higher-resolution image stacks (b) are used for spine analysis. Scale bars $100 \mu \mathrm{m}$ (a) $10 \mu \mathrm{m}$ (b).

In APP/PS1 mice, this technique shows that oligomeric $A \beta$ is in fact present at a subset of shrunken excitatory postsynaptic densities, particularly in a halo of oligomeric $\mathrm{A} \beta$ surrounding the dense cores of plaques [56]. As would be predicted from the association of dendritic spine changes with physiological plasticity [57-59] and the presence of oligomeric $A \beta$ at shrinking spines, dendritic spines can recover with therapeutic interventions aimed at removing oligomeric $A \beta$ or inhibiting calcineurin which is activated downstream of $A \beta$ associated increases in intracellular calcium [30, 39, 60-62]. Removing soluble $\mathrm{A} \beta$ with the topical application of the 3D6 antibody allows rapid increases in the structural plasticity of dendritic spines within one hour, before any clearance of fibrillar $\mathrm{A} \beta$ occurs [30].

Tau overexpression has also been associated with spine loss in postmortem studies of human tau transgenic animals [25]. In rTg4510 mice, pyramidal cells have reduced spine density compared to wild-type animals, but tanglebearing neurons have no more loss than their non-tanglebearing neighbors [25]. Similarly rTg4510 hippocampal circuits are deficient in experience-dependent upregulation of immediate early genes compared to wild-type mice, but tangle-bearing neurons are not impaired compared to nontangle-bearing cells in rTg4510 brain [63]. In vivo and array tomography imaging of tangles in rTg4510 mice has been developed and is demonstrating similar indications that soluble tau may be more toxic than fibrillar tau in terms of axonal transport and neuronal death [64-68]. In cultured neurons and transgenic mice overexpressing tau, mislocalization of tau to dendritic spines disrupts synaptic function [69].

Very recent data elegantly link $\mathrm{A} \beta$, tau, and dendritic spine loss $[70,71]$. Ittner et al. established that tau has a dendritic function in targeting the Src kinase Fyn to dendritic spines. Fyn phosphorylates NMDA receptor NR2 subunits mediating their interaction with the postsynaptic scaffolding protein PSD95 and disrupting this interaction of tau, and Fyn prevents $A \beta$ toxicity in APP transgenic mice [70]. Similarly, Roberson et al. found that $\mathrm{A} \beta$, tau, and Fyn jointly impair synaptic network function in electrophysiological studies of APP and Fyn overexpressing mice on a tau null background [71]. In culture, oligomeric $A \beta$ was found to cause tau mislocalization to dendrites which was associated with local calcium elevation and dendritic spine loss [72].

\section{Synaptic Plasticity Is Severely Impaired in AD Mouse Models}

It is widely accepted that, in early stages of $\mathrm{AD}$, synaptic dysfunction is the cause of dementia [84, 85]. Synaptic plasticity provides a neurophysiological substrate for learning and memory and is, therefore, often used to evaluate the phenotype of transgenic mice. In APP transgenic AD mouse models, there are significant alterations in hippocampal synaptic transmission and plasticity at excitatory glutamatergic synapses that sometimes appear in young animals long before $\mathrm{A} \beta$ is deposited in plaques (see Table 1 ). Most studies performed before mice reached 6 months of age report intact basal synaptic transmission [75, 78, 81, 83] although some exceptions were also reported $[74,86]$. It should be noted that the lack of detectable changes in basal synaptic transmission in the majority of studies does not rule out synaptic dysfunction that has been overcome by functional compensation. Indeed, evidence of functional compensation in response to spine loss induced by $\mathrm{A} \beta$ has been observed in several models [87-89]. From 6 months on, most of the $\mathrm{AD}$ transgenic mice show significant deficits in basal synaptic transmission $[75,78,79,81-83,90]$. This age-related deterioration in synaptic transmission in $\mathrm{AD}$ transgenic mice is unlikely to result from a decreased transmitter release probability because paired-pulse facilitation (PPF), which correlates inversely with the probability of transmitter release 
TABLE 1: Progressive synaptic malfunction AD transgenic mice.

\begin{tabular}{|c|c|c|c|c|c|}
\hline Model & Mutations & $\begin{array}{c}\text { Age } \\
\text { (months) }\end{array}$ & Basal synaptic transmission & Long-term potentiation & $\begin{array}{c}\text { Paired-pulse } \\
\text { facilitation }\end{array}$ \\
\hline \multirow{4}{*}{$\operatorname{Tg} 2576$} & \multirow{4}{*}{ APPswe } & $2-3$ & & Impaired [73] & \\
\hline & & $4-6$ & Impaired [74] & Normal [74]/impaired [73] & \\
\hline & & $6-12$ & Impaired [75] & & Normal [75] \\
\hline & & $>12$ & Normal [76, 77]/Impaired [75] & Normal [75]/impaired $[76,77]$ & Normal $[4,6]$ \\
\hline \multirow{3}{*}{ PDAPP } & \multirow{3}{*}{$\mathrm{APP}(\mathrm{V} 717 \mathrm{~F})$} & $<6$ & Normal [78] & Impaired [78] & Impaired [78] \\
\hline & & $6-12$ & & & \\
\hline & & $>12$ & Impaired [78] & Normal [78] & Impaired [78] \\
\hline \multirow{3}{*}{ APP/PS1 } & \multirow{3}{*}{ APPswe/PS1dE9 } & $<6$ & Normal [79] & Impaired $[79,80]$ & \\
\hline & & $6-12$ & Impaired $[79,80]$ & Impaired $[79,80]$ & Normal [80] \\
\hline & & $>12$ & & & \\
\hline \multirow{4}{*}{$3 x T g-A D$} & \multirow{4}{*}{ APPSwe, PS1M146V, and tauP301L } & $1-2$ & Normal $[81]$ & Normal $[81]$ & Normal [81] \\
\hline & & $3-6$ & & & \\
\hline & & $6-12$ & Impaired [81] & Impaired [81] & Normal $[81]$ \\
\hline & & $>12$ & & & \\
\hline \multirow{3}{*}{ 5XFAD } & \multirow{3}{*}{$\begin{array}{l}\mathrm{APP}_{\text {swe/lnd/fl }} \text { and a PS1 transgene } \\
\text { carrying double FAD mutations } \\
(\mathrm{M} 146 \mathrm{~L} \text { and } \mathrm{L} 286 \mathrm{~V})\end{array}$} & $<6$ & Normal [82] & Normal [82] & Normal [82] \\
\hline & & $6-12$ & Impaired $[82,83]$ & Impaired $[82,83]$ & Normal [82] \\
\hline & & $>12$ & & & \\
\hline
\end{tabular}

[78], remains intact in most of $\mathrm{AD}$ transgenic mice, even at advanced ages $[78,86]$ (see Table 1 ). Impairments in longterm potentiation (LTP) were shown both in vitro and in vivo, in the CA1 as well as dentate gyrus regions of the hippocampus $[76,91]$. Failure of LTP expression is detected in AD mice in some cases before 4 months of age $[73,78]$ but usually appears later $[75,76,81-83,86,92]$, when $A \beta$ load is higher. These findings emphasize the fact that extracellular deposition of fibrillar $A \beta$ is not required for the development of severe functional deficits in AD models. This conclusion is strengthened by the observation that direct application of $\mathrm{A} \beta$ oligomers into the brain prevents LTP $[48,93,94]$.

Studies of the mechanisms of $\mathrm{A} \beta$-mediated synaptic dysfunction converge on the theme of increased postsynaptic calcium concentrations leading to internalization of NMDA and AMPA receptors via mechanisms similar to those seen in long-term depression $[40,42,95,96]$. Overall, these findings suggest that synaptic dysfunction is an early event in AD pathogenesis and may play a role in the disease process.

\section{Impaired Cognition in AD Mouse Models}

Learning and memory processes are believed to depend on changes of synaptic transmission in certain areas of the brain, including the hippocampus. Most studies done with $\mathrm{AD}$ transgenic mice assess spatial navigation capability (e.g., Morris water maze, radial maze, Barnes maze) since this memory system depends on the hippocampus and is highly conserved in mammals [97]. The onset of cognitive decline is difficult to define in humans, particularly without a reliable biomarker. Thus, the use of transgenic mouse models to address this question is particularly useful, since the early cognitive changes can be identified and correlated with molecular and cellular changes. The implication of $\mathrm{A} \beta$ in the cognitive decline in $\mathrm{AD}$ transgenic mice is no longer controversial. However, there were contrasting reports regarding the onset of cognitive decline in different $\mathrm{AD}$ models (Table 2). In some studies, deficits in learning and memory were observed at 3 months, implicating soluble $\mathrm{A} \beta$ assemblies [98, 99], while other studies have shown onsets at intermediate ages [76, 98, 100-104] or at advanced ages $[100,101,105,106]$, invoking insoluble $\mathrm{A} \beta$ plaques. Moreover, in the $3 \mathrm{XTg}-\mathrm{AD}$ mouse model, spatial longterm retention memory deficits were found to correlate with intraneuronal $\mathrm{A} \beta$ at 4 months [81], an age when these transgenic mice do not have $A \beta$ plaques [107]. A similar observation has been shown for $5 \mathrm{x}$ FAD mice, which also accumulate high amounts of intraneuronal $\mathrm{A} \beta$ peptides [108] and present with significant impairment in the working memory already at 4-5 months of age [102, 103]. Due to this controversy, the $\mathrm{A} \beta$ species responsible for the cognitive decline in these mice was under debate for many years. Strong evidence for the toxicity of soluble $A \beta$ came from a study showing that naturally secreted soluble $\mathrm{A} \beta$ oligomers administrated into the rat's lateral cerebral ventricles at picomolar concentrations disrupt the memory of a complex learned behavior [47]. This suggests that soluble $\mathrm{A} \beta$ oligomers, rather than $\mathrm{A} \beta$ plaques, may be responsible for the cognitive impairment in the absence of $A \beta$ plaques or neuronal death.

Although aged AD mice are impaired at learning several tasks that depend on the hippocampus, the performance of these mice on tasks requiring an intact amygdala, such as cued-fear conditioning, has been thoroughly established only for $\operatorname{Tg} 2576$ mice $[112,119]$ and aged APP/PS1 mice [15]. In these models amygdala-dependent learning is severely impaired at advanced ages, implying that neurons of 
TABLE 2: Progressive cognitive impairments in APP AD transgenic mice.

\begin{tabular}{|c|c|c|c|c|c|c|}
\hline \multirow{2}{*}{ Model } & \multirow{2}{*}{$\begin{array}{c}\text { Age } \\
\text { (months) }\end{array}$} & \multicolumn{2}{|c|}{ Spatial task } & \multirow{2}{*}{ Working memory } & \multicolumn{2}{|c|}{ Fear conditioning } \\
\hline & & Learning & Probe test & & Contextual & Cued \\
\hline \multirow{3}{*}{$\operatorname{Tg} 2576$} & $<6$ & $\begin{array}{c}\text { Impaired }[109] / \text { normal } \\
{[98,100,110]}\end{array}$ & Normal $[100,111]$ & $\begin{array}{c}\text { Normal [110]/impaired } \\
{[98]}\end{array}$ & $\begin{array}{c}\text { Impaired } \\
{[74,109,112-118]}\end{array}$ & Normal [119] \\
\hline & $6-12$ & $\begin{array}{c}\text { Normal }[101] / \text { impaired } \\
{[110,120]}\end{array}$ & $\begin{array}{l}\text { Normal [120]/ } \\
\text { impaired [111] }\end{array}$ & $\begin{array}{c}\text { Normal } \\
{[98,101] / \text { impaired }[110]}\end{array}$ & $\begin{array}{c}\text { Impaired } \\
{[115,121] / \text { normal }[122]}\end{array}$ & Normal [122] \\
\hline & $>12$ & Impaired $[101,110]$ & Impaired [111] & $\begin{array}{c}\text { Impaired } \\
{[76,98,101,110]}\end{array}$ & Impaired $[112,115,117]$ & $\begin{array}{c}\text { Normal [112, } \\
\text { 119]/impaired } \\
\text { [119] }\end{array}$ \\
\hline \multirow{3}{*}{ APP/PS1 } & $<6$ & Normal [123-128] & $\begin{array}{l}\text { Normal }[126,127] / \\
\text { impaired }[128]\end{array}$ & $\begin{array}{c}\text { Normal }[124,127,129, \\
130] / \text { impaired }[80]\end{array}$ & $\begin{array}{c}\text { Normal } \\
{[131-133] / \text { impaired }} \\
{[79,117] / \text { enhanced }} \\
{[127]}\end{array}$ & \\
\hline & $6-12$ & $\begin{array}{c}\text { Impaired } \\
{[79,80,105,126-} \\
128,134]\end{array}$ & $\begin{array}{c}\text { Normal }[105,127, \\
134] / \text { impaired } \\
{[79,80,126,128]}\end{array}$ & $\begin{array}{c}\text { Impaired } \\
{[80,127,129,130]}\end{array}$ & $\begin{array}{c}\text { Impaired [79]/normal } \\
{[127]}\end{array}$ & \\
\hline & $>12$ & $\begin{array}{c}\text { Impaired } \\
{[105,106,124,128,135]}\end{array}$ & Impaired $[105,106]$ & Impaired $[124,129]$ & & Impaired [15] \\
\hline \multirow{4}{*}{$3 x T g-A D$} & $1-2$ & Normal [107] & Normal [107] & Normal $[107,136]$ & & \\
\hline & $3-6$ & Impaired [137-139] & $\begin{array}{c}\text { Impaired } \\
{[107,137,138]}\end{array}$ & Normal [136] & & \\
\hline & $6-12$ & Impaired $[107,140]$ & $\begin{array}{c}\text { Impaired } \\
{[107,139,140]}\end{array}$ & Impaired $[136,139,141]$ & Impaired [139] & \\
\hline & $>12$ & & Impaired [142] & Impaired $[141,143]$ & & \\
\hline \multirow{3}{*}{ 5XFAD } & $<6$ & & Impaired $[108,144]$ & Normal $[102,108]$ & Normal $[82,145]$ & Normal [144] \\
\hline & $6-12$ & Impaired [144] & & Impaired $[102,103]$ & Impaired $[82,144,145]$ & \\
\hline & $>12$ & & & Impaired $[102,103,146]$ & & \\
\hline
\end{tabular}

the amygdala, similar to hippocampal neurons, are susceptible to the toxic effect of $\mathrm{A} \beta$.

At later stages of the disease, widespread synaptic and neuronal death probably contribute greatly to dementia. These effects are likely mediated by tau downstream of the initiating amyloid pathology [18]. Reflecting this later stage of dementia, tau-expressing mouse lines which undergo neuronal loss develop behavioral deficits. Interestingly, two of these mouse lines which have reversible expression of pathological tau exhibit recovery of cognition after transgene suppression even after extensive neuron loss [147, 148]. These studies point to the powerful ability of synapses to regenerate and allow functional recovery of neural circuits if the toxic insult in the disease can be removed.

\section{Conclusions}

The data presented in this paper are from a strong body of literature supporting the hypothesis that oligomeric $\mathrm{A} \beta$ accumulation in the brain initiates the disease process in $\mathrm{AD}$ by impairing structural and functional plasticity of synapses. This underlies behavioral deficits observed in APP mouse models which begin before $\mathrm{A} \beta$ deposition in plaques and continue after plaque deposition when the plaques appear to be a reservoir of oligomeric $\mathrm{A} \beta$ causing local structural and functional disruptions. Downstream of the initial amyloid insult, tau pathology contributes to synapse and neuronal loss and consequent cognitive decline. AD transgenic mice are characterized by a number of specific cognitive deficits, compatible with $\mathrm{AD}$, which makes them indispensable for testing of novel anti-AD drugs. Finally, the plastic nature of synapses and their clear involvement in both early and late stages of cognitive decline in these AD models highlight the importance of synaptic targets for therapeutic approaches.

\section{References}

[1] A. Alzheimer, "Ubereine eigenartige erkrankung der hirnrinde," Allgemeine Zeitschrift fur Psychiatrie und PsychischGerichtliche Medizin, vol. 64, pp. 146-148, 1907.

[2] M. Goedert and M. G. Spillantini, "A century of Alzheimer's disease," Science, vol. 314, no. 5800, pp. 777-781, 2006.

[3] K. M. Harris, "Structure, development, and plasticity of dendritic spines," Current Opinion in Neurobiology, vol. 9, no. 3, pp. 343-348, 1999.

[4] R. D. Terry, E. Masliah, D. P. Salmon et al., "Physical basis of cognitive alterations in Alzheimer's disease: synapse loss is the major correlate of cognitive impairment," Annals of Neurology, vol. 30, no. 4, pp. 572-580, 1991.

[5] S. T. DeKosky, S. W. Scheff, and S. D. Styren, "Structural correlates of cognition in dementia: quantification and assessment of synapse change," Neurodegeneration, vol. 5, no. 4, pp. 417-421, 1996.

[6] P. D. Coleman and P. J. Yao, "Synaptic slaughter in Alzheimer's disease," Neurobiology of Aging, vol. 24, no. 8, pp. 1023-1027, 2003. 
[7] T. L. Spires and B. T. Hyman, "Neuronal structure is altered by amyloid plaques," Reviews in the Neurosciences, vol. 15, no. 4, pp. 267-278, 2004.

[8] D. J. Selkoe, "Amyloid $\beta$-protein and the genetics of Alzheimer's disease," Journal of Biological Chemistry, vol. 271, no. 31, pp. 18295-18298, 1996.

[9] M. Hutton, "Molecular genetics of chromosome 17 tauopathies," Annals of the New York Academy of Sciences, vol. 920, pp. 63-73, 2000.

[10] M. Hutton, C. L. Lendon, P. Rizzu et al., "Association of missense and 5'-splice-site mutations in tau with the inherited dementia FTDP-17," Nature, vol. 393, no. 6686, pp. 702-705, 1998.

[11] T. L. Spires and B. T. Hyman, "Transgenic models of Alzheimer's disease: learning from animals," NeuroRx, vol. 2, no. 3, pp. 423-437, 2005.

[12] D. Games, D. Adams, R. Alessandrini et al., "Alzheimer-type neuropathology in transgenic mice overexpressing V717F $\beta$ amyloid precursor protein," Nature, vol. 373, no. 6514, pp. 523-527, 1995.

[13] S. Knafo, L. Alonso-Nanclares, J. Gonzalez-Soriano et al., "Widespread changes in dendritic spines in a model of Alzheimer's Disease," Cerebral Cortex, vol. 19, no. 3, pp. 586592, 2009.

[14] P. Merino-Serrais, S. Knafo, L. Alonso-Nanclares, I. FernaudEspinosa, and J. DeFelipe, "Layer-specific alterations to CA1 dendritic spines in a mouse model of Alzheimer's disease," Hippocampus, vol. 21, no. 10, pp. 1037-1044, 2011.

[15] S. Knafo, C. Venero, P. Merino-Serrais et al., "Morphological alterations to neurons of the amygdala and impaired fear conditioning in a transgenic mouse model of Alzheimer's disease," Journal of Pathology, vol. 219, no. 1, pp. 41-51, 2009.

[16] J. P. Brion, K. Ando, C. Heraud, and K. Leroy, "Modulation of tau pathology in tau transgenic models," Biochemical Society Transactions, vol. 38, no. 4, pp. 996-1000, 2010.

[17] J. Gotz, N. Deters, A. Doldissen et al., "A decade of tau transgenic animal models and beyond," Brain Pathology, vol. 17, no. 1, pp. 91-103, 2007.

[18] B. T. Hyman, "Amyloid-dependent and amyloid-independent stages of Alzheimer disease," Archives of Neurology, vol. 68, no. 8, pp. 1062-1064, 2011.

[19] T. A. Lanz, D. B. Carter, and K. M. Merchant, "Dendritic spine loss in the hippocampus of young PDAPP and Tg2576 mice and its prevention by the ApoE2 genotype," Neurobiology of Disease, vol. 13, no. 3, pp. 246-253, 2003.

[20] D. L. Moolman, O. V. Vitolo, J. P. G. Vonsattel, and M. L. Shelanski, "Dendrite and dendritic spine alterations in Alzheimer models," Journal of Neurocytology, vol. 33, no. 3, pp. 377-387, 2004.

[21] T. L. Spires, M. Meyer-Luehmann, E. A. Stern et al., "Dendritic spine abnormalities in amyloid precursor protein transgenic mice demonstrated by gene transfer and intravital multiphoton microscopy," Journal of Neuroscience, vol. 25, no. 31, pp. 7278-7287, 2005.

[22] J. Tsai, J. Grutzendler, K. Duff, and W. B. Gan, "Fibrillar amyloid deposition leads to local synaptic abnormalities and breakage of neuronal branches," Nature Neuroscience, vol. 7, no. 11, pp. 1181-1183, 2004.

[23] A. Alpár, U. Ueberham, M. K. Brückner, G. Seeger, T. Arendt, and U. Gärtner, "Different dendrite and dendritic spine alterations in basal and apical arbors in mutant human amyloid precursor protein transgenic mice," Brain Research, vol. 1099, no. 1, pp. 189-198, 2006.
[24] A. B. Rocher, M. S. Kinson, and J. I. Luebke, "Significant structural but not physiological changes in cortical neurons of 12-month-old Tg2576 mice," Neurobiology of Disease, vol. 32, no. 2, pp. 309-318, 2008.

[25] A. B. Rocher, J. L. Crimins, J. M. Amatrudo et al., "Structural and functional changes in tau mutant mice neurons are not linked to the presence of NFTs," Experimental Neurology, vol. 223, no. 2, pp. 385-393, 2010.

[26] A. Holtmaat, T. Bonhoeffer, D. K. Chow et al., "Long-term, high-resolution imaging in the mouse neocortex through a chronic cranial window," Nature Protocols, vol. 4, no. 8, pp. 1128-1144, 2009.

[27] A. J. Holtmaat, J. T. Trachtenberg, L. Wilbrecht et al., "Transient and persistent dendritic spines in the neocortex in vivo," Neuron, vol. 45, no. 2, pp. 279-291, 2005.

[28] J. T. Trachtenberg, B. E. Chen, G. W. Knott et al., "Long-term in vivo imaging of experience-dependent synaptic plasticity in adult cortex," Nature, vol. 420, no. 6917, pp. 788-794, 2002.

[29] G. Feng, R. H. Mellor, M. Bernstein et al., "Imaging neuronal subsets in transgenic mice expressing multiple spectral variants of GFP," Neuron, vol. 28, no. 1, pp. 41-51, 2000.

[30] T. L. Spires-Jones, M. L. Mielke, A. Rozkalne et al., "Passive immunotherapy rapidly increases structural plasticity in a mouse model of Alzheimer disease," Neurobiology of Disease, vol. 33, no. 2, pp. 213-220, 2009.

[31] Z. Lai and R. O. Brady, "Gene transfer into the central nervous system in vivo using a recombinanat lentivirus vector," Journal of Neuroscience Research, vol. 67, no. 3, pp. 363-371, 2002.

[32] B. J. Bacskai, G. A. Hickey, J. Skoch et al., "Four-dimensional multiphoton imaging of brain entry, amyloid binding, and clearance of an amyloid- $\beta$ ligand in transgenic mice," Proceedings of the National Academy of Sciences of the United States of America, vol. 100, no. 21, pp. 12462-12467, 2003.

[33] B. J. Bacskai, S. T. Kajdasz, R. H. Christie et al., "Imaging of amyloid- $\beta$ deposits in brains of living mice permits direct observation of clearance of plaques with immunotherapy," Nature Medicine, vol. 7, no. 3, pp. 369-372, 2001.

[34] R. Christie, E. Kimchi, S. Kajdasz, B. Bacskai, and B. T. Hyman, "Multiphoton microscopy and amyloid angiopathy," Amyloid, vol. 8, no. 1, pp. 48-50, 2001.

[35] R. H. Christie, B. J. Bacskai, W. R. Zipfel et al., "Growth arrest of individual senile plaques in a model of Alzheimer's disease observed by in vivo multiphoton microscopy," Journal of Neuroscience, vol. 21, no. 3, pp. 858-864, 2001.

[36] M. Meyer-Luehmann, T. L. Spires-Jones, C. Prada et al., "Rapid appearance and local toxicity of amyloid- $\beta$ plaques in a mouse model of Alzheimer's disease," Nature, vol. 451, no. 7179, pp. 720-724, 2008.

[37] T. L. Spires-Jones, M. Meyer-Luehmann, J. D. Osetek et al., "Impaired spine stability underlies plaque-related spine loss in an Alzheimer's disease mouse model," American Journal of Pathology, vol. 171, no. 4, pp. 1304-1311, 2007.

[38] M. Meyer-Luehmann, M. Mielke, T. L. Spires-Jones et al., "A reporter of local dendritic translocation shows plaquerelated loss of neural system function in APP-transgenic mice," Journal of Neuroscience, vol. 29, no. 40, pp. 1263612640, 2009.

[39] K. V. Kuchibhotla, S. T. Goldman, C. R. Lattarulo, H. Y. Wu, B. T. Hyman, and B. J. Bacskai, "A $\beta$ plaques lead to aberrant regulation of calcium homeostasis in vivo resulting in structural and functional disruption of neuronal networks," Neuron, vol. 59, no. 2, pp. 214-225, 2008. 
[40] E. M. Snyder, Y. Nong, C. G. Almeida et al., "Regulation of NMDA receptor trafficking by amyloid- $\beta$," Nature Neuroscience, vol. 8, no. 8, pp. 1051-1058, 2005.

[41] M. P. Lambert, A. K. Barlow, B. A. Chromy et al., "Diffusible, nonfibrillar ligands derived from A $\beta 1-42$ are potent central nervous system neurotoxins," Proceedings of the National Academy of Sciences of the United States of America, vol. 95, no. 11, pp. 6448-6453, 1998.

[42] H. Hsieh, J. Boehm, C. Sato et al., "AMPAR removal underlies A $\beta$-induced synaptic depression and dendritic spine loss," Neuron, vol. 52, no. 5, pp. 831-843, 2006.

[43] G. M. Shankar, B. L. Bloodgood, M. Townsend, D. M. Walsh, D. J. Selkoe, and B. L. Sabatini, "Natural oligomers of the Alzheimer amyloid- $\beta$ protein induce reversible synapse loss by modulating an NMDA-type glutamate receptordependent signaling pathway," Journal of Neuroscience, vol. 27, no. 11, pp. 2866-2875, 2007.

[44] W. Wei, L. N. Nguyen, H. W. Kessels, H. Hagiwara, S. Sisodia, and R. Malinow, "Amyloid beta from axons and dendrites reduces local spine number and plasticity," Nature Neuroscience, vol. 13, no. 2, pp. 190-196, 2010.

[45] S. Lesné, T. K. Ming, L. Kotilinek et al., "A specific amyloid- $\beta$ protein assembly in the brain impairs memory," Nature, vol. 440, no. 7082, pp. 352-357, 2006.

[46] S. Lesné, L. Kotilinek, and K. H. Ashe, "Plaque-bearing mice with reduced levels of oligomeric amyloid- $\beta$ assemblies have intact memory function," Neuroscience, vol. 151, no. 3, pp. 745-749, 2008.

[47] J. P. Cleary, D. M. Walsh, J. J. Hofmeister et al., "Natural oligomers of the amyloid- $\beta$ protein specifically disrupt cognitive function," Nature Neuroscience, vol. 8, no. 1, pp. 7984, 2005.

[48] D. M. Walsh, I. Klyubin, J. V. Fadeeva et al., "Naturally secreted oligomers of amyloid $\beta$ protein potently inhibit hippocampal long-term potentiation in vivo," Nature, vol. 416, no. 6880, pp. 535-539, 2002.

[49] R. P. Brendza, B. J. Bacskai, J. R. Cirrito et al., "Anti-A $\beta$ antibody treatment promotes the rapid recovery of amyloidassociated neuritic dystrophy in PDAPP transgenic mice," Journal of Clinical Investigation, vol. 115, no. 2, pp. 428-433, 2005.

[50] M. Buttini, E. Masliah, R. Barbour et al., “ $\beta$-amyloid immunotherapy prevents synaptic degeneration in a mouse model of Alzheimer's disease," Journal of Neuroscience, vol. 25, no. 40, pp. 9096-9101, 2005.

[51] J. C. Dodart, K. R. Bales, K. S. Gannon et al., "Immunization reverses memory deficits without reducing brain $\mathrm{A} \beta$ burden in Alzheimer's disease model," Nature Neuroscience, vol. 5, no. 5, pp. 452-457, 2002.

[52] D. Games, F. Bard, H. Grajeda et al., "Prevention and reduction of AD-type pathology in PDAPP mice immunized with A $\beta$ 1-42," Annals of the New York Academy of Sciences, vol. 920, pp. 274-284, 2000.

[53] J. A. Lombardo, E. A. Stern, M. E. McLellan et al., "Amyloid$\beta$ antibody treatment leads to rapid normalization of plaqueinduced neuritic alterations," Journal of Neuroscience, vol. 23, no. 34, pp. 10879-10883, 2003.

[54] K. D. Micheva, B. Busse, N. C. Weiler, N. O’Rourke, and S. J. Smith, "Single-synapse analysis of a diverse synapse population: proteomic imaging methods and markers," Neuron, vol. 68, no. 4, pp. 639-653, 2010.

[55] K. D. Micheva and S. J. Smith, "Array tomography: a new tool for imaging the molecular architecture and ultrastructure of neural circuits," Neuron, vol. 55, no. 1, pp. 25-36, 2007.
[56] R. M. Koffie, M. Meyer-Luehmann, T. Hashimoto et al., "Oligomeric amyloid $\beta$ associates with postsynaptic densities and correlates with excitatory synapse loss near senile plaques," Proceedings of the National Academy of Sciences of the United States of America, vol. 106, no. 10, pp. 4012-4017, 2009.

[57] Q. Zhou, K. J. Homma, and M. M. Poo, "Shrinkage of dendritic spines associated with long-term depression of hippocampal synapses," Neuron, vol. 44, no. 5, pp. 749-757, 2004.

[58] N. Bastrikova, G. A. Gardner, J. M. Reece, A. Jeromin, and S. M. Dudek, "Synapse elimination accompanies functional plasticity in hippocampal neurons," Proceedings of the National Academy of Sciences of the United States of America, vol. 105, no. 8, pp. 3123-3127, 2008.

[59] R. Yuste and T. Bonhoeffer, "Morphological changes in dendritic spines associated with long-term synaptic plasticity," Annual Review of Neuroscience, vol. 24, pp. 1071-1089, 2001.

[60] A. Rozkalne, B. T. Hyman, and T. L. Spires-Jones, "Calcineurin inhibition with FK506 ameliorates dendritic spine density deficits in plaque-bearing Alzheimer model mice," Neurobiology of Disease, vol. 41, no. 3, pp. 650-654, 2011.

[61] A. Rozkalne, T. L. Spires-Jones, E. A. Stern, and B. T. Hyman, "A single dose of passive immunotherapy has extended benefits on synapses and neurites in an Alzheimer's disease mouse model," Brain Research, vol. 1280, pp. 178-185, 2009.

[62] H.-Y. Wu, E. Hudry, T. Hashimoto et al., "Amyloid $\beta$ induces the morphological neurodegenerative triad of spine loss, dendritic simplification, and neuritic dystrophies through calcineurin activation," Journal of Neuroscience, vol. 30, no. 7, pp. 2636-2649, 2010.

[63] L. M. Fox, C. M. William, D. H. Adamowicz et al., "Soluble tau species, not neurofibrillary aggregates, disrupt neural system integration in a tau transgenic model," Journal of Neuropathology and Experimental Neurology, vol. 70, no. 7, pp. 588-595, 2011.

[64] A. de Calignon, L. M. Fox, R. Pitstick et al., "Caspase activation precedes and leads to tangles," Nature, vol. 464, no. 7292, pp. 1201-1204, 2010.

[65] A. de Calignon, T. L. Spires-Jones, R. Pitstick, G. A. Carlson, and B. T. Hyman, "Tangle-bearing neurons survive despite disruption of membrane integrity in a mouse model of tauopathy," Journal of Neuropathology and Experimental Neurology, vol. 68, no. 7, pp. 757-761, 2009.

[66] K. J. Kopeikina, G. A. Carlson, R. Pitstick et al., "Tau accumulation causes mitochondrial distribution deficits in neurons in a mouse model of tauopathy and in human Alzheimer's disease brain," American Journal of Pathology, vol. 179, no. 4, pp. 2071-2082, 2011.

[67] T. L. Spires-Jones, A. de Calignon, T. Matsui et al., "In vivo imaging reveals dissociation between caspase activation and acute neuronal death in tangle-bearing neurons," Journal of Neuroscience, vol. 28, no. 4, pp. 862-867, 2008.

[68] T. L. Spires-Jones, W. H. Stoothoff, A. de Calignon, P. B. Jones, and B. T. Hyman, "Tau pathophysiology in neurodegeneration: a tangled issue," Trends in Neurosciences, vol. 32, no. 3, pp. 150-159, 2009.

[69] B. R. Hoover, M. N. Reed, J. Su et al., "Tau mislocalization to dendritic spines mediates synaptic dysfunction independently of neurodegeneration," Neuron, vol. 68, no. 6, pp. 1067-1081, 2010.

[70] L. M. Ittner, Y. D. Ke, F. Delerue et al., "Dendritic function of tau mediates amyloid- $\beta$ toxicity in alzheimer's disease mouse models," Cell, vol. 142, no. 3, pp. 387-397, 2010. 
[71] E. D. Roberson, B. Halabisky, J. W. Yoo et al., "Amyloid$\beta /$ fyn-induced synaptic, network, and cognitive impairments depend on tau levels in multiple mouse models of Alzheimer's disease," Journal of Neuroscience, vol. 31, no. 2, pp. 700-711, 2011.

[72] H. Zempel, E. Thies, E. Mandelkow, and E. M. Mandelkow, "A $\beta$ oligomers cause localized $\mathrm{Ca}^{2+}$ elevation, missorting of endogenous tau into dendrites, tau phosphorylation, and destruction of microtubules and spines," Journal of Neuroscience, vol. 30, no. 36, pp. 11938-11950, 2010.

[73] T. Ma, C. A. Hoeffer, E. Capetillo-Zarate et al., "Dysregulation of the mTOR pathway mediates impairment of synaptic plasticity in a mouse model of Alzheimer's disease," PLoS ONE, vol. 5, no. 9, Article ID e12845, pp. 1-10, 2010.

[74] M. D'Amelio, V. Cavallucci, S. Middei et al., "Caspase-3 triggers early synaptic dysfunction in a mouse model of Alzheimer's disease," Nature Neuroscience, vol. 14, no. 1, pp. 69-79, 2011.

[75] S. M. Fitzjohn, R. A. Morton, F. Kuenzi et al., "Agerelated impairment of synaptic transmission but normal potentiation in transgenic mice that overexpress the human APP695SWE mutant form of amyloid precursor protein," Journal of Neuroscience, vol. 21, no. 13, pp. 4691-4698, 2001.

[76] P. F. Chapman, G. L. White, M. W. Jones et al., "Impaired synaptic plasticity and learning in aged amyloid precursor protein transgenic mice," Nature Neuroscience, vol. 2, no. 3, pp. 271-276, 1999.

[77] J. Jung, K. An, O. B. Kwon, H. S. Kim, and J.-H. Kim, "Pathway-specific alteration of synaptic plasticity in Tg2576 mice," Molecules and Cells, pp. 1-5, 2011.

[78] J. Larson, G. Lynch, D. Games, and P. Seubert, "Alterations in synaptic transmission and long-term potentiation in hippocampal slices from young and aged PDAPP mice," Brain Research, vol. 840, no. 1-2, pp. 23-35, 1999.

[79] B. Gong, O. V. Vitolo, F. Trinchese, S. Liu, M. Shelanski, and O. Arancio, "Persistent improvement in synaptic and cognitive functions in an Alzheimer mouse model after rolipram treatment," Journal of Clinical Investigation, vol. 114, no. 11, pp. 1624-1634, 2004.

[80] F. Trinchese, S. Liu, F. Battaglia, S. Walter, P. M. Mathews, and O. Arancio, "Progressive age-related development of Alzheimer-like pathology in APP/PS1 mice," Annals of Neurology, vol. 55, no. 6, pp. 801-814, 2004.

[81] S. Oddo, A. Caccamo, J. D. Shepherd et al., "Triple-transgenic model of Alzheimer's disease with plaques and tangles: intracellular A $\beta$ and synaptic dysfunction," Neuron, vol. 39, no. 3, pp. 409-421, 2003.

[82] R. Kimura and M. Ohno, "Impairments in remote memory stabilization precede hippocampal synaptic and cognitive failures in 5XFAD Alzheimer mouse model," Neurobiology of Disease, vol. 33, no. 2, pp. 229-235, 2009.

[83] R. Kimura, L. Devi, and M. Ohno, "Partial reduction of BACE1 improves synaptic plasticity, recent and remote memories in Alzheimer's disease transgenic mice," Journal of Neurochemistry, vol. 113, no. 1, pp. 248-261, 2010.

[84] D. J. Selkoe, "Alzheimer's disease is a synaptic failure," Science, vol. 298, no. 5594, pp. 789-791, 2002.

[85] R. E. Tanzi, "The synaptic A $\beta$ hypothesis of Alzheimer disease," Nature Neuroscience, vol. 8, no. 8, pp. 977-979, 2005.

[86] A. Y. Hsia, E. Masliah, L. Mcconlogue et al., "Plaqueindependent disruption of neural circuits in Alzheimer's disease mouse models," Proceedings of the National Academy of Sciences of the United States of America, vol. 96, no. 6, pp. 3228-3233, 1999.
[87] S. Middei, A. Roberto, N. Berretta et al., "Learning discloses abnormal structural and functional plasticity at hippocampal synapses in the APP23 mouse model of Alzheimer's disease," Learning and Memory, vol. 17, no. 5, pp. 236-240, 2010.

[88] C. Perez-Cruz, M. W. Nolte, M. M. van Gaalen et al., "Reduced spine density in specific regions of CA1 pyramidal neurons in two transgenic mouse models of Alzheimer's disease," Journal of Neuroscience, vol. 31, no. 10, pp. 39263934, 2011.

[89] D. L. Smith, J. Pozueta, B. Gong, O. Arancio, and M. Shelanski, "Reversal of long-term dendritic spine alterations in Alzheimer disease models," Proceedings of the National Academy of Sciences of the United States of America, vol. 106, no. 39, pp. 16877-16882, 2009.

[90] F. Trinchese, M. Fa', S. Liu et al., "Inhibition of calpains improves memory and synaptic transmission in a mouse model of Alzheimer disease," Journal of Clinical Investigation, vol. 118, no. 8, pp. 2796-2807, 2008.

[91] I. Klyubin, D. M. Walsh, C. A. Lemere et al., "Amyloid $\beta$ protein immunotherapy neutralizes $\mathrm{A} \beta$ oligomers that disrupt synaptic plasticity in vivo," Nature Medicine, vol. 11, no. 5, pp. 556-561, 2005.

[92] D. Moechars, I. Dewachter, K. Lorent et al., "Early phenotypic changes in transgenic mice that overexpress different mutants of amyloid precursor protein in brain," Journal of Biological Chemistry, vol. 274, no. 10, pp. 6483-6492, 1999.

[93] I. Klyubin, V. Betts, A. T. Welzel et al., "Amyloid $\beta$ protein dimer-containing human CSF disrupts synaptic plasticity: prevention by systemic passive immunization," Journal of Neuroscience, vol. 28, no. 16, pp. 4231-4237, 2008.

[94] D. J. Selkoe, "Soluble oligomers of the amyloid $\beta$-protein impair synaptic plasticity and behavior," Behavioural Brain Research, vol. 192, no. 1, pp. 106-113, 2008.

[95] I. Goussakov, M. B. Miller, and G. E. Stutzmann, "NMDAmediated $\mathrm{Ca}^{2+}$ influx drives aberrant ryanodine receptor activation in dendrites of young Alzheimer's disease mice," Journal of Neuroscience, vol. 30, no. 36, pp. 12128-12137, 2010.

[96] Z. Li, J. Jo, J. M. Jia et al., "Caspase-3 activation via mitochondria is required for long-term depression and AMPA receptor internalization," Cell, vol. 141, no. 5, pp. 859871, 2010.

[97] L. R. Squire, "Memory and the hippocampus: a synthesis from findings with rats, monkeys, and humans," Psychological Review, vol. 99, no. 2, pp. 195-231, 1992.

[98] D. L. King and G. W. Arendash, "Behavioral characterization of the Tg2576 transgenic model of Alzheimer's disease through 19 months," Physiology and Behavior, vol. 75, no. 5, pp. 627-642, 2002.

[99] D. L. King, G. W. Arendash, F. Crawford, T. Sterk, J. Menendez, and M. J. Mullan, "Progressive and genderdependent cognitive impairment in the APP(SW) transgenic mouse model for Alzheimer's disease," Behavioural Brain Research, vol. 103, no. 2, pp. 145-162, 1999.

[100] K. Hsiao, P. Chapman, S. Nilsen et al., "Correlative memory deficits, $\mathrm{A} \beta$ elevation, and amyloid plaques in transgenic mice," Science, vol. 274, no. 5284, pp. 99-103, 1996.

[101] D. Morgan, D. M. Diamond, P. E. Gottschall et al., "A $\beta$ peptide vaccination prevents memory loss in an animal model of Alzheimer's disease," Nature, vol. 408, no. 6815, pp. 982-985, 2000.

[102] S. Jawhar, A. Trawicka, C. Jenneckens, T. A. Bayer, and O. Wirths, "Motor deficits, neuron loss, and reduced anxiety coinciding with axonal degeneration and intraneuronal $\mathrm{A} \beta$ 
aggregation in the 5XFAD mouse model of Alzheimer's disease," Neurobiol Aging, vol. 33, no. 1, pp. 196.e29-196.e40, 2012.

[103] L. Devi and M. Ohno, "Phospho-eIF2 $\alpha$ level is important for determining abilities of BACE1 reduction to rescue cholinergic neurodegeneration and memory defects in 5XFAD mice," PLoS ONE, vol. 5, no. 9, Article ID e12974, 2010.

[104] P. N. Pompl, M. J. Mullan, K. Bjugstad, and G. W. Arendash, "Adaptation of the circular platform spatial memory task for mice: use in detecting cognitive impairment in the APP(sw) transgenic mouse model for Alzheimer's disease," Journal of Neuroscience Methods, vol. 87, no. 1, pp. 87-95, 1999.

[105] R. Minkeviciene, J. Ihalainen, T. Malm et al., "Age-related decrease in stimulated glutamate release and vesicular glutamate transporters in APP/PS1 transgenic and wild-type mice," Journal of Neurochemistry, vol. 105, no. 3, pp. 584-594, 2008.

[106] T. M. Malm, H. Iivonen, G. Goldsteins et al., "Pyrrolidine dithiocarbamate activates Akt and improves spatial learning in APP/PS1 mice without affecting $\hat{\mathrm{I}}^{2}$-amyloid burden," Journal of Neuroscience, vol. 27, no. 14, pp. 3712-3721, 2007.

[107] L. M. Billings, S. Oddo, K. N. Green, J. L. McGaugh, and F. M. LaFerla, "Intraneuronal A $\beta$ causes the onset of early Alzheimer's disease-related cognitive deficits in transgenic mice," Neuron, vol. 45, no. 5, pp. 675-688, 2005.

[108] H. Oakley, S. L. Cole, S. Logan et al., "Intraneuronal $\hat{\mathrm{I}}^{2}$ amyloid aggregates, neurodegeneration, and neuron loss in transgenic mice with five familial Alzheimer's disease mutations: potential factors in amyloid plaque formation," Journal of Neuroscience, vol. 26, no. 40, pp. 10129-10140, 2006.

[109] C. Perez-Cruz, M. W. Nolte, M. M. van Gaalen et al., "Reduced spine density in specific regions of CA1 pyramidal neurons in two transgenic mouse models of Alzheimer's disease," Journal of Neuroscience, vol. 31, no. 10, pp. 39263934, 2011.

[110] G. Chen, K. S. Chen, J. Knox et al., "A learning deficit related to age and $\beta$-amyloid plaques in a mouse model of Alzheimer's disease," Nature, vol. 408, no. 6815, pp. 975-979, 2000.

[111] M. A. Westerman, D. Cooper-Blacketer, A. Mariash et al., "The relationship between $\mathrm{AI}^{2}$ and memory in the $\mathrm{Tg} 2576$ mouse model of Alzheimer's disease," Journal of Neuroscience, vol. 22, no. 5, pp. 1858-1867, 2002.

[112] K. A. Corcoran, Y. Lu, R. Scott Turner, and S. Maren, "Overexpression of hAPPswe impairs rewarded alternation and contextual fear conditioning in a transgenic mouse model of Alzheimer's disease," Learning and Memory, vol. 9, no. 5, pp. 243-252, 2002.

[113] B. P. Imbimbo, L. Giardino, S. Sivilia et al., "CHF5074, a novel $\gamma$-secretase modulator, restores hippocampal neurogenesis potential and reverses contextual memory deficit in a transgenic mouse model of Alzheimer's disease," Journal of Alzheimer's Disease, vol. 20, no. 1, pp. 159-173, 2010.

[114] T. A. Comery, R. L. Martone, S. Aschmies et al., "Acute $\hat{\mathrm{I}}^{3}$ secretase inhibition improves contextual fear conditioning in the Tg2576 mouse model of Alzheimer's disease," Journal of Neuroscience, vol. 25, no. 39, pp. 8898-8902, 2005.

[115] J. S. Jacobsen, C. C. Wu, J. M. Redwine et al., "Earlyonset behavioral and synaptic deficits in a mouse model of Alzheimer's disease," Proceedings of the National Academy of Sciences of the United States of America, vol. 103, no. 13, pp. 5161-5166, 2006.
[116] D. R. Riddell, H. Zhou, T. A. Comery et al., "The LXR agonist TO901317 selectively lowers hippocampal A $\beta 42$ and improves memory in the $\operatorname{Tg} 2576$ mouse model of Alzheimer's disease," Molecular and Cellular Neuroscience, vol. 34, no. 4, pp. 621-628, 2007.

[117] K. T. Dineley, X. Xia, D. Bui, J. D. Sweatt, and H. Zheng, "Accelerated plaque accumulation, associative learning deficits, and up-regulation of $\hat{\mathrm{I}} \pm 7$ nicotinic receptor protein in transgenic mice co-expressing mutant human presenilin 1 and amyloid precursor proteins," Journal of Biological Chemistry, vol. 277, no. 25, pp. 22768-22780, 2002.

[118] J. S. Jacobsen, C. C. Wu, J. M. Redwine et al., "Earlyonset behavioral and synaptic deficits in a mouse model of Alzheimer's disease," Proceedings of the National Academy of Sciences of the United States of America, vol. 103, no. 13, pp. 5161-5166, 2006.

[119] P. Barnes and M. Good, "Impaired pavlovian cued fear conditioning in $\operatorname{Tg} 2576$ mice expressing a human mutant amyloid precursor protein gene," Behavioural Brain Research, vol. 157, no. 1, pp. 107-117, 2005.

[120] M. Tabuchi, T. Yamaguchi, S. Iizuka, S. Imamura, Y. Ikarashi, and Y. Kase, "Ameliorative effects of yokukansan, a traditional Japanese medicine, on learning and non-cognitive disturbances in the Tg2576 mouse model of Alzheimer's disease," Journal of Ethnopharmacology, vol. 122, no. 1, pp. 157-162, 2009.

[121] D. R. Thakker, M. R. Weatherspoon, J. Harrison et al., "Intracerebroventricular amyloid- $\hat{\mathrm{I}}^{2}$ antibodies reduce cerebral amyloid angiopathy and associated micro-hemorrhages in aged Tg2576 mice," Proceedings of the National Academy of Sciences of the United States of America, vol. 106, no. 11, pp. 4501-4506, 2009.

[122] H. Dong, B. Goico, M. Martin, C. A. Csernansky, A. Bertchume, and J. G. Csernansky, "Modulation of hippocampal cell proliferation, memory, and amyloid plaque deposition in APPsw (Tg2576) mutant mice by isolation stress," Neuroscience, vol. 127, no. 3, pp. 601-609, 2004.

[123] M. Filali, R. Lalonde, and S. Rivest, "Subchronic memantine administration on spatial learning, exploratory activity, and nest-building in an APP/PS1 mouse model of Alzheimer's disease," Neuropharmacology, vol. 60, no. 6, pp. 930-936, 2011.

[124] G. W. Arendash, D. L. King, M. N. Gordon et al., "Progressive, age-related behavioral impairments in transgenic mice carrying both mutant amyloid precursor protein and presenilin-1 transgenes," Brain Research, vol. 891, no. 1-2, pp. 42-53, 2001.

[125] F. Trinchese, S. Liu, F. Battaglia, S. Walter, P. M. Mathews, and O. Arancio, "Progressive age-related development of Alzheimer-like pathology in APP/PS1 mice," Annals of Neurology, vol. 55, no. 6, pp. 801-814, 2004.

[126] Y. Yu, J. He, Y. Zhang et al., "Increased hippocampal neurogenesis in the progressive stage of Alzheimer's disease phenotype in an APP/PS1 double transgenic mouse model," Hippocampus, vol. 19, no. 12, pp. 1247-1253, 2009.

[127] G. A. Scullion, D. A. Kendalla, C. A. Marsdena, D. Sunterc, and M.-C. Pardona, "Chronic treatment with the $\alpha_{2}$-adrenoceptor antagonist fluparoxan prevents age-related deficits in spatial working memory in APP $\times$ PS1 transgenic mice without altering $\beta$-amyloid plaque load or astrocytosis," Neuropharmacology, vol. 60, no. 2-3, pp. 223-234, 2011.

[128] J. Puoliväli, J. Wang, T. Heikkinen et al., "Hippocampal A $\beta 42$ levels correlate with spatial memory deficit in APP and PS1 
double transgenic mice," Neurobiology of Disease, vol. 9, no. 3, pp. 339-347, 2002.

[129] O. Wirths, H. Breyhan, S. Schäfer, C. Roth, and T. A. Bayer, "Deficits in working memory and motor performance in the APP/PS1ki mouse model for Alzheimer's disease," Neurobiology of Aging, vol. 29, no. 6, pp. 891-901, 2008.

[130] M.-C. Cotel, S. Jawhar, D. Z. Christensen, T. A. Bayer, and O. Wirths, "Environmental enrichment fails to rescue working memory deficits, neuron loss, and neurogenesis in APP/PS1 KI mice," Neurobiol Aging, vol. 33, no. 1, pp. 96-107, 2012.

[131] M. C. Pardon, S. Sarmad, I. Rattray et al., "Repeated novel cage exposure-induced improvement of early Alzheimer'slike cognitive and amyloid changes in TASTPM mice is unrelated to changes in brain endocannabinoids levels," Neurobiology of Aging, vol. 30, no. 7, pp. 1099-1113, 2009.

[132] I. Rattray, G. A. Scullion, A. Soulby, D. A. Kendall, and M. C. Pardon, "The occurrence of a deficit in contextual fear extinction in adult amyloid-over-expressing TASTPM mice is independent of the strength of conditioning but can be prevented by mild novel cage stress," Behavioural Brain Research, vol. 200, no. 1, pp. 83-90, 2009.

[133] I. Rattray, A. Pitiot, J. Lowe et al., "Novel cage stress alters remote contextual fear extinction and regional $\mathrm{T}_{2}$ magnetic resonance relaxation times in TASTPM mice overexpressing amyloid," Journal of Alzheimer's Disease, vol. 20, no. 4, pp. 1049-1068, 2010.

[134] J. L. Jankowsky, T. Melnikova, D. J. Fadale et al., "Environmental enrichment mitigates cognitive deficits in a mouse model of Alzheimer's disease," Journal of Neuroscience, vol. 25, no. 21, pp. 5217-5224, 2005.

[135] L. Liu, S. Ikonen, T. Heikkinen, T. Tapiola, T. van Groen, and H. Tanila, "The effects of long-term treatment with metrifonate, a cholinesterase inhibitor, on cholinergic activity, amyloid pathology, and cognitive function in APP and PS1 doubly transgenic mice," Experimental Neurology, vol. 173, no. 2, pp. 196-204, 2002.

[136] J. C. Carroll, E. R. Rosario, L. Chang et al., "Progesterone and estrogen regulate Alzheimer-like neuropathology in female 3xTg-AD mice," Journal of Neuroscience, vol. 27, no. 48, pp. 13357-13365, 2007.

[137] H. Guan, Y. Liu, A. Daily et al., "Peripherally expressed neprilysin reduces brain amyloid burden: a novel approach for treating Alzheimer's disease," Journal of Neuroscience Research, vol. 87, no. 6, pp. 1462-1473, 2009.

[138] A. C. McKee, I. Carreras, L. Hossain et al., "Ibuprofen reduces $\mathrm{A} \beta$, hyperphosphorylated tau and memory deficits in Alzheimer mice," Brain Research, vol. 1207, pp. 225-236, 2008.

[139] A. Caccamo, S. Oddo, L. M. Billings et al., "M1 receptors play a central role in modulating $\mathrm{AD}$-like pathology in transgenic mice," Neuron, vol. 49, no. 5, pp. 671-682, 2006.

[140] A. Caccamo, M. A. Maldonado, A. F. Bokov, S. Majumder, and S. Oddo, "CBP gene transfer increases BDNF levels and ameliorates learning and memory deficits in a mouse model of Alzheimer's disease," Proceedings of the National Academy of Sciences of the United States of America, vol. 107, no. 52, pp. 22687-22692, 2010.

[141] E. R. Rosario, J. C. Carroll, S. Oddo, F. M. LaFerla, and C. J. Pike, "Androgens regulate the development of neuropathology in a triple transgenic mouse model of Alzheimer's disease," The Journal of Neuroscience, vol. 26, no. 51, pp. 13384-13389, 2006.
[142] Y. Matsuoka, Y. Jouroukhin, A. J. Gray et al., "A neuronal microtubule-interacting agent, NAPVSIPQ, reduces tau pathology and enhances cognitive function in a mouse model of Alzheimer's disease," Journal of Pharmacology and Experimental Therapeutics, vol. 325, no. 1, pp. 146-153, 2008.

[143] S. Oddo, V. Vasilevko, A. Caccamo, M. Kitazawa, D. H. Cribbs, and F. M. LaFerla, "Reduction of soluble $\mathrm{AI}^{2}$ and tau, but not soluble $\mathrm{AI}^{2}$ alone, ameliorates cognitive decline in transgenic mice with plaques and tangles," Journal of Biological Chemistry, vol. 281, no. 51, pp. 39413-39423, 2006.

[144] M. Ohno, L. Chang, W. Tseng et al., "Temporal memory deficits in Alzheimer's mouse models: rescue by genetic deletion of BACE1," European Journal of Neuroscience, vol. 23, no. 1, pp. 251-260, 2006.

[145] L. Devi and M. Ohno, "Genetic reductions of $\beta$-site amyloid precursor protein-cleaving enzyme 1 and amyloid- $\beta$ ameliorate impairment of conditioned taste aversion memory in 5XFAD Alzheimer's disease model mice," European Journal of Neuroscience, vol. 31, no. 1, pp. 110-118, 2010.

[146] M. Ohno, S. L. Cole, M. Yasvoina et al., "BACE1 gene deletion prevents neuron loss and memory deficits in 5XFAD APP/PS1 transgenic mice," Neurobiology of Disease, vol. 26, no. 1, pp. 134-145, 2007.

[147] K. Santacruz, J. Lewis, T. Spires et al., "Tau suppression in a neurodegenerative mouse model improves memory function," Science, vol. 309, no. 5733, pp. 476-481, 2005.

[148] A. Sydow, A. van der Jeugd, F. Zheng et al., "Tau-induced defects in synaptic plasticity, learning, and memory are reversible in transgenic mice after switching off the toxic tau mutant," Journal of Neuroscience, vol. 31, no. 7, pp. 25112525, 2011. 

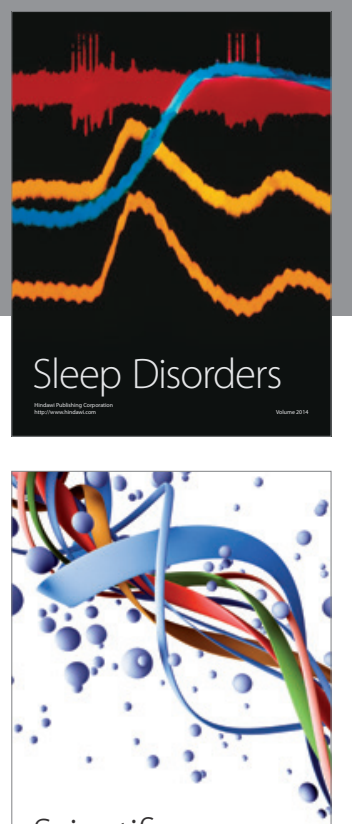

Scientifica
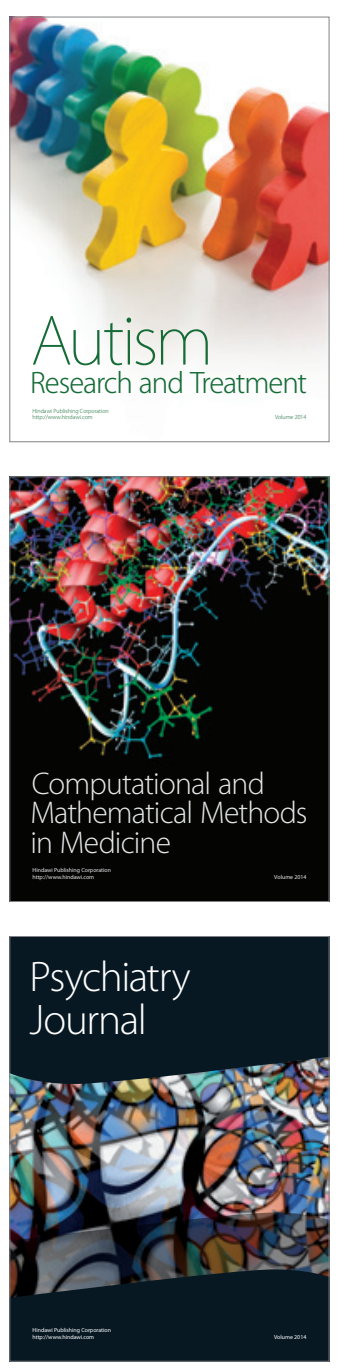
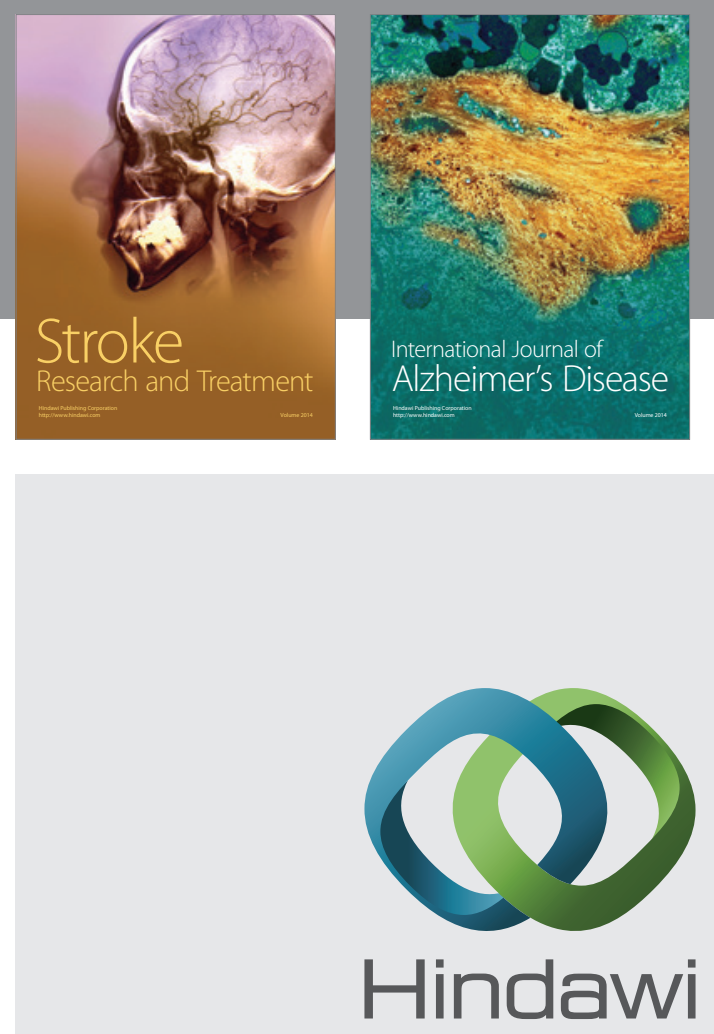

Submit your manuscripts at

http://www.hindawi.com
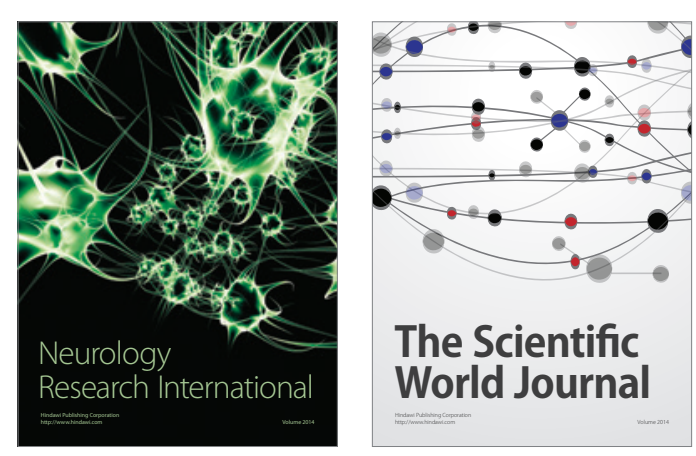

The Scientific World Journal

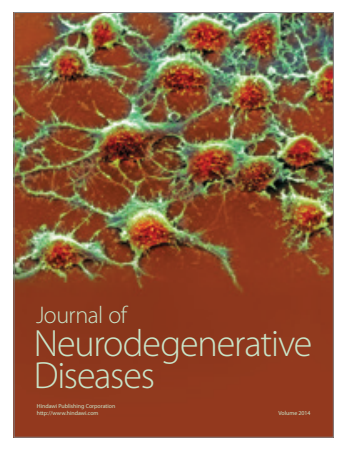

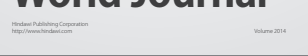

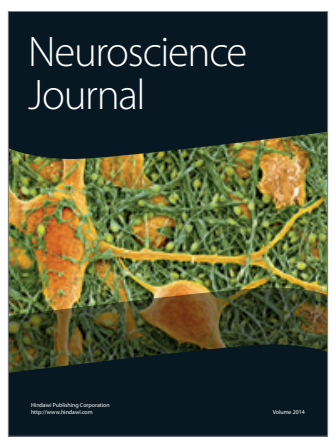

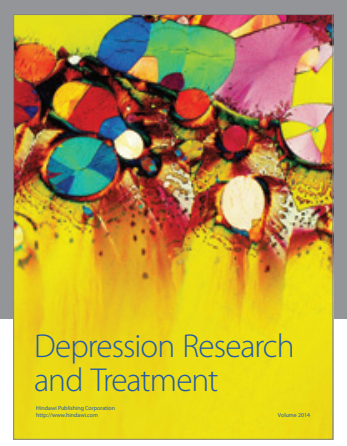
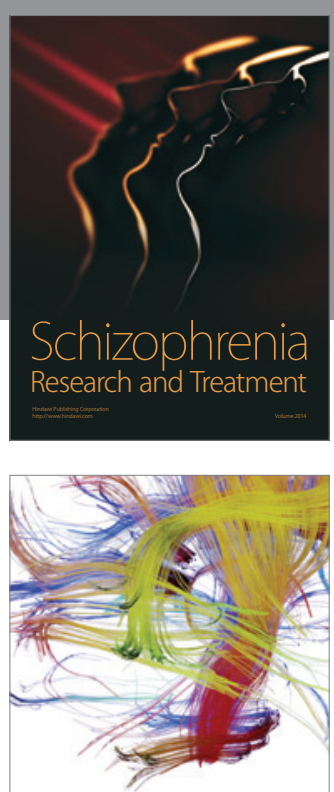

Brain Science

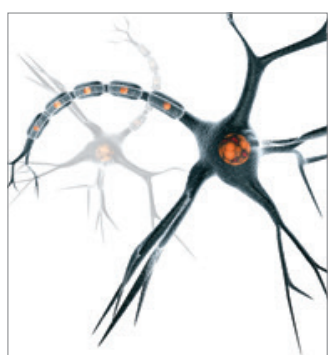

Neural Plasticity
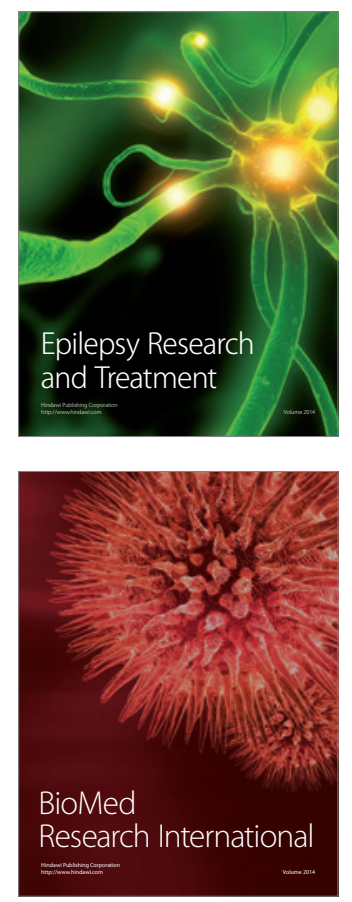

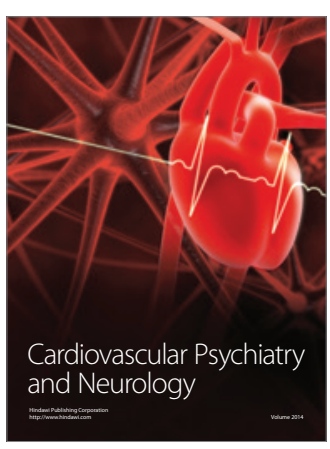

Parkinson's

Disease
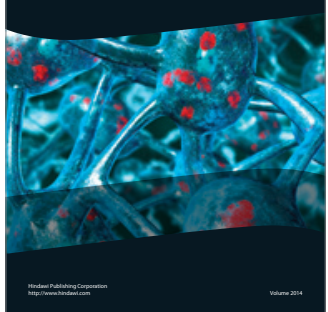